J. Perinat. Med. $13(1985) 43$

\section{The concentration of hypoxanthine and lactate in the blood of healthy and hypoxic newborns}

\author{
D. Jung, A. Lun*, J. Zinsmeyer*, E. L. Grauel, J. Gross* \\ Department of Neonatology, Children Hospital, and \\ * Department of Pathological and Clinical Biochemistry, Charité, \\ Humboldt University, Berlin, GDR
}

\section{Introduction}

The extraordinary importance of an accurate recognition and evaluation of perinatal hypoxia begs the question for valid indicators of hypoxia. Since the 1950's the determination of lactate [5] has been discussed in this respect; more recently work by SAUGSTAD $[17,18]$ in determining hypoxanthine levels in the plasma of neonates has found wide attention. Elevated hypoxanthine levels under hypoxic conditions have been documented in many studies in animals $[19,20,22,24$, $25]$, as well as human newborns $[2,7,13,17,21$, 23].

In this work we will present reference data of hypoxanthine and lactate levels in healthy mature newborns in the first five days of life, as well as those in newborns requiring oxygen therapy, and those in well prematures. We will also present correlations between levels of hypoxanthine and lactate, the clinical course, and parameters of acidbase balance.

\section{Patients, material, and methods}

Group A: In order to establish reference values, hypoxanthine and lactate were determined in the blood of healthy mature newborn infants (37-42 gestational weeks). All infants had APGAR scores $\geqslant 8$, a postnatal course without complications and no clinical or other biochemical indicators of

\section{Curriculum vitae}

Dr. DIETMAR JUNG was horn in 1955 in Kyritz (District of Potsdam). He attended the Medical School at Ilumboldt University in Berlin from 1976 to 1982. He obtained his doctoral degree in 1983 with a disserlation on neonatal hypoxia, his particular area of continuing interest. Currently, the author holds an appoint. ment at the District Neurological Hospital in Neuruppin, German Democratic Republic.

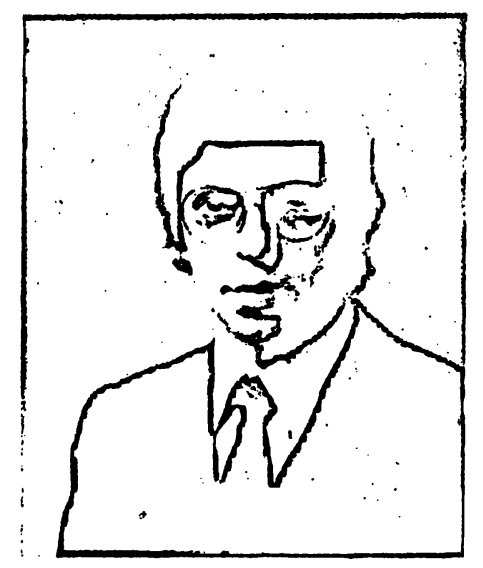

hypoxia. Blood levels were determined on day 1 (for hypoxanthine $n=44$, for lactate $n=41$ ), day $3(n=46$ and $n=41$ respectively), and day 5 $(n=46$ and $n=44)$. For 36 (hypoxanthine) and 30 (lactate) of these neonates serial determinations for a longitudinal study were available.

Group B: was comprised of 18 well prematures ( $\leqslant 37$ gestational weeks, no clinical or biochemical indicators of hypoxia); there were 18 hypoxanthine and 16 lactate determinations.

Group C: Newborns with clinical or biochemical symptoms leading to respiratory support either by ventilator or CPAP underwent in 36 cases (29 prematures, 7 term infants) a hypoxanthine determination and in 31 cases (24 prematures and 7 term infants) determination of the lactate concen- 
tration in the blood. In addition to the determinations of hypoxanthine and lactate a number of these infants requiring respiratory support had determinations of acid-base balance $(\mathrm{pH}$ base deficit, $\mathrm{O}_{2}$ saturation), $\mathrm{pO}_{2}$, hemoglobin and hematocrit.

There were no statistically significant difference between Groups B and C in respect to gestational or postnatal age; none of the infants were older than 5 days.

For the infants in Group C we compared the hypoxanthine and lactate levels with the clinical state of the infant and the acid-base values. An elevated hypoxanthine or lactate concentration was defined as values above 2 standard deviations (log transformation) of the control group (Group A). The mean values found in Group A were not significantly different from those in Group B. Unequivocal clinical indicators of hypoxia were abnormalities in the cardiotocogram, or five minute APGAR scores under 7 (for values on day 1), and cyanosis with normal hematocrit values. Low limits of acid-base values indicative of hypoxia for capillary blood values were $\mathrm{pH}$ $<7.30, \quad \mathrm{pO}_{2}<5.33 \mathrm{kPa}$ and base deficit $>5 \mathrm{mmol} / \mathrm{l}$ as being markedly outside the limits of normal. Transcutaneous $\mathrm{pO}_{2}$ measurements were not available at the time of the study.

Hypoxanthine was determined according to GARDINER [3] fluorimetrically in blood following protein precipitation with uranyl acetate. For the determination of lactate blood was precipitated with perchlorate for an optical assay according to HOHORST [4]. Both assays were performed on capillary blood $[6,9,14,28]$.

The frequency distribution of hypoxanthine and lactate reference data for the various days of life were tested for normal and log-normal distribution [15]. The U-test by MANN and WHITNEY [27] served as test for significant differences.

\section{Results}

There is a log-normal distribution for the levels of hypoxanthine $(p>0.1)$ and lactate $(p>0.05)$ in the healthy mature newborns (Group A) for each tested day of life. There are no sex differences for hypoxanthine or lactate $(p>0.1)$. The age dependent normal ranges for hypoxanthine and lactate levels are depicted in Tab. I and II. Based on the logarithmic distribution data have been recomputed for linear plotting. The levels of hypoxanthine decrease noticably with increasing age $(p<0.001)$.

The lactate level drops from the first to the third postnatal day $(p<0.001)$ but no difference was found between the values for day 3 and day 5 $(p>0.1)$.

In Tabs.III and IV the mean values and ranges of the hypoxanthine and lactate levels in well pre-

Tab. I. Hypoxanthine in the blood of mature healthy newborns ( $\mu \mathrm{mol} / 1)$

\begin{tabular}{llll}
\hline Age & $\mathrm{n}$ & $\overline{\mathrm{x}}$ & 2 SD range \\
\hline Day 1 $(12-36 \mathrm{~h})$ & 44 & 5.5 & $2.7-11.2$ \\
Day 3 $(60-84 \mathrm{~h})$ & 46 & 3.2 & $1.3-7.9$ \\
Day 5 $(108-132 \mathrm{~h})$ & 46 & 1.8 & $0.6-5.7$ \\
\hline
\end{tabular}

Tab. II. Lactate in the blood of mature healthy newborns (mmol/1)

\begin{tabular}{llll}
\hline Age & $\mathrm{n}$ & $\overline{\mathrm{x}}$ & 2 SD range \\
\hline Day 1 $(12-36 \mathrm{~h})$ & 41 & 2.0 & $1.4-2.9$ \\
Day 3 $(60-84 \mathrm{~h})$ & 41 & 1.6 & $1.0-2.5$ \\
Day 5 $(108-132 \mathrm{~h})$ & 44 & 1.5 & $0.9-2.5$ \\
\hline
\end{tabular}

Tab. III. Hypoxanthine in blood of well prematures $(\mu \mathrm{mol} / 1)$

\begin{tabular}{lrll}
\hline Age & $\mathrm{n}$ & $\overline{\mathbf{x}}$ & Range \\
\hline Day 1 & 10 & 5.4 & $3.1-16.0$ \\
Day 2-3 & 5 & 2.7 & $0.7-5.7$ \\
Day 5 & 3 & 2.3 & $1.3-5.0$ \\
\hline
\end{tabular}

Tab. IV. Lactate in blood of well prematures (mmol/1)

\begin{tabular}{lrll}
\hline Age & $\mathrm{n}$ & $\overline{\mathrm{x}}$ & Range \\
\hline Day 1 & 10 & 1.9 & $1.0-2.7$ \\
Day 2-3 & 4 & 2.0 & $1.4-2.4$ \\
Day 5 & 2 & 1.5 & $1.4-1.5$ \\
\hline
\end{tabular}


Tab. V. Correlation of hypoxanthine and lactate levels with the clinical course and blood gas values in infants requiring respiratory therapy.

\begin{tabular}{|c|c|c|c|c|}
\hline & $\begin{array}{l}\text { Hypoxar } \\
\text { elevated }\end{array}$ & $\begin{array}{l}\text { ine } \\
\text { normal }\end{array}$ & $\begin{array}{l}\text { Lactate } \\
\text { elevated }\end{array}$ & normal \\
\hline $\begin{array}{l}\text { Newborns } \\
\text { with } \\
\text { hypoxic } \\
\text { signs } \\
\text { Newborns } \\
\text { without } \\
\text { hypoxic } \\
\text { signs }\end{array}$ & 5 & 26 & 7 & 18 \\
\hline
\end{tabular}

HYPOXANTHINE HMOI/I

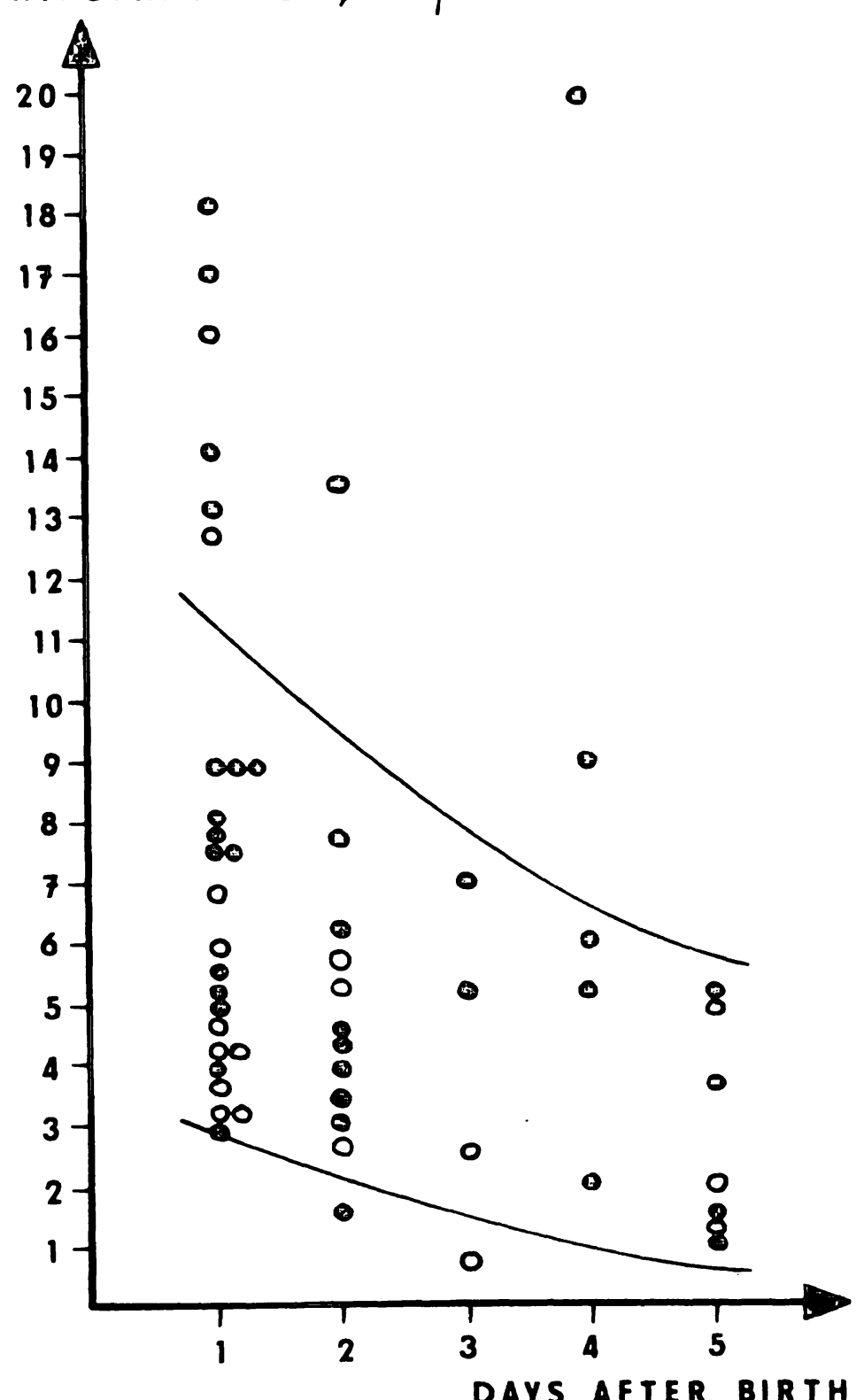

Fig. 1. Hypoxanthine level in the blood of 36 infants requiring respiratory support $(\bullet)$ and 18 well prematures (o). The two standard deviation range for the mature healthy newborn is indicated. matures (Group B) are listed again, appreciating the log-normal distribution. It is apparent that the hypoxanthine and lactate levels in Group B infants have a very similar age dependent course as Group A infants; a significant decline in values is only present from day 1 to day $5(\mathrm{p}<0.05)$.

Fig. 1 depicts the hypoxanthine levels found in the blood of infants in Groups B and C. Values above the norm were found in two instances in Group B and seven times in Group C.

Fig. 2 gives data for the determination of lactate. There were no pathological lactate values in the

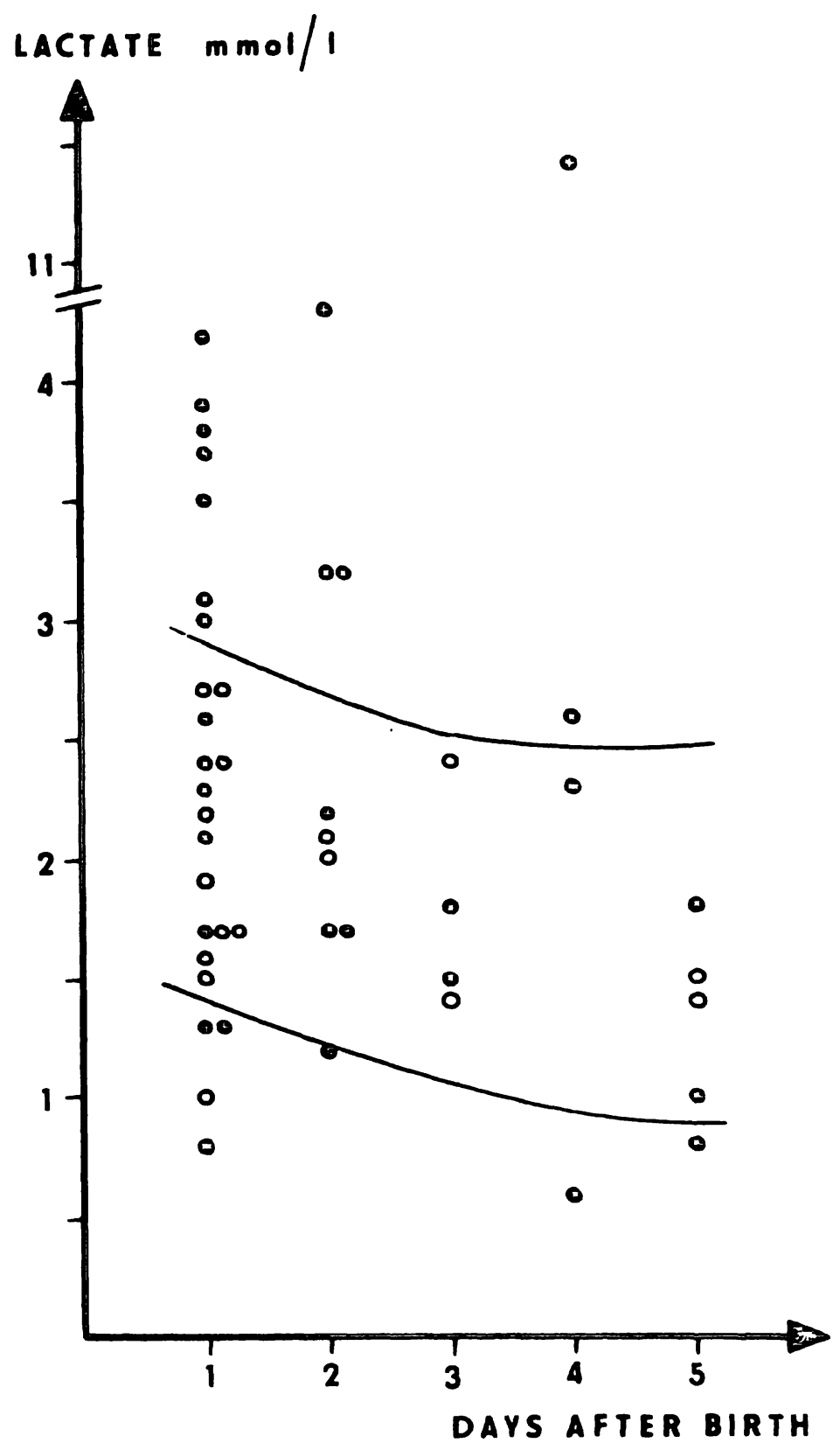

Fig. 2. Lactate level in the blood of 31 infants requiring respiratory $(\bullet)$ and 16 well prematures $(0)$. The two standard deviation range for the mature healthy newborn is indicated. 
well prematures. There were 12 values above the two standard deviation limit in those requiring respiratory therapy.

$\mathrm{Tab} . \mathrm{V}$ indicates the extent to which Group C infants the hypoxanthine and lactate levels correlated with the defined indicators of hypoxia.

The following cases demonstrate that infants with an unequivocal diagnosis of hypoxia by clinical, $\mathrm{pO}_{2}$, and acid-base criteria may have elevated as well as normal hypoxanthine and lactate levels. Conversely, infants without clinical or biochemical correlates of hypoxia may have had elevated hypoxanthine or lactate values.

Case 1: 40 weeks gestation, birth weight 2900 grams, APGAR scores 7, 8, 9, 9; initially unremarkable course. On the fourth day of life dyspnea, rales, seizures necessitating respiratory treatment. Blood gases following intubation, $\mathrm{pH} 7.19, \mathrm{pO}_{2}$ (capillary) $7.86 \mathrm{kPa}, \mathrm{pCO}_{2}$ $6.40 \mathrm{kPa}, \mathrm{BE}-11 \mathrm{mmol} / \mathrm{l}$; hypoxanthine $20.9 \mu \mathrm{mol} / 1$ (elevated), lactate $11.4 \mathrm{mmol} / 1$ (elevated). Patient died.on the sixth day of life with a diagnosis of congenital purulent pneumonia.

Case 2: 33 weeks gestation, Cesearean section because of late decelerations, birth weight 1740 grams, APGAR 2, $3,-,-$; patient was intubated and ventilated and required continued buffer therapy. On the fifth day of life, still moderately cyanotic. Blood gases: $\mathrm{pH} 7.50, \mathrm{pO}_{2} 4.93 \mathrm{kPa}$, $\mathrm{pCO}_{2} 6.00 \mathrm{kPa}$, BE $6 \mathrm{mmol} / \mathrm{l}$; hypoxanthine $3.7 \mu \mathrm{mol} / 1$ (normal), lactate $1.8 \mathrm{mmol} / 1$ (normal).

Case 3: 38th gestational week, birth weight 2670 grams, APGAR 9, 10, 10, 9. On the first day dyspnea developed, nasal CPAP was initiated. Blood gases: $7.28 \mathrm{pO}_{2} 6.93 \mathrm{kPa}$, $\mathrm{pCO}_{2} 6.93 \mathrm{kPa}, \mathrm{BE} 3 \mathrm{mmol} / \mathrm{l}$; hypoxanthine $14.1 \mu \mathrm{mol} / 1$ (elevated), lactate $1.3 \mathrm{mmol} / 1$ (normal).

Case 4: 34th gestational week, birth weight 1590 grams, APGAR 5, 8, 8, 10; pH in the umbilical arteries 7.33. Diagnosis PIERRE ROBIN Syndrome. The infant was placed in an incubator and given oxygen. Blood gases at the age of four hours: $\mathrm{pH} 7.31, \mathrm{pO}_{2} 5,86 \mathrm{kPa}, \mathrm{pCO}_{2} 6.66$ $\mathrm{kPa}$, BE $2 \mathrm{mmol} / \mathrm{l}$; hypoxanthine $8.0 \mathrm{~mol} / 1$ (normal), lactate $3.0 \mathrm{mmol} / 1$ (elevated).

There was a correlation between hypoxanthine and lactate values in Group A on day $1(\mathrm{r}=0.48$, $\mathrm{p}<0.01)$ and day $5(\mathrm{r}=0.36, \mathrm{p}<0.05)$. Similarly, within Groups $\mathrm{B}$ and $\mathrm{C}$ each the hypoxanthine and lactate concentrations correlated as follows: Group B: $r=0.56, p<0.05$; Group C: $r=0.64$, $\mathrm{p}<0.001$ ) (Fig. 3). There were no statistically significant correlations between hypoxanthine and lactate levels in the blood of the infants with respiratory support to any parameter of acid-base balance ( $\mathrm{pH}, \mathrm{pO}_{2}$, base deficit, oxygen saturation). Likewise, hypoxanthine and lactate values did not correlate with hemoglobin or hematocrit values.

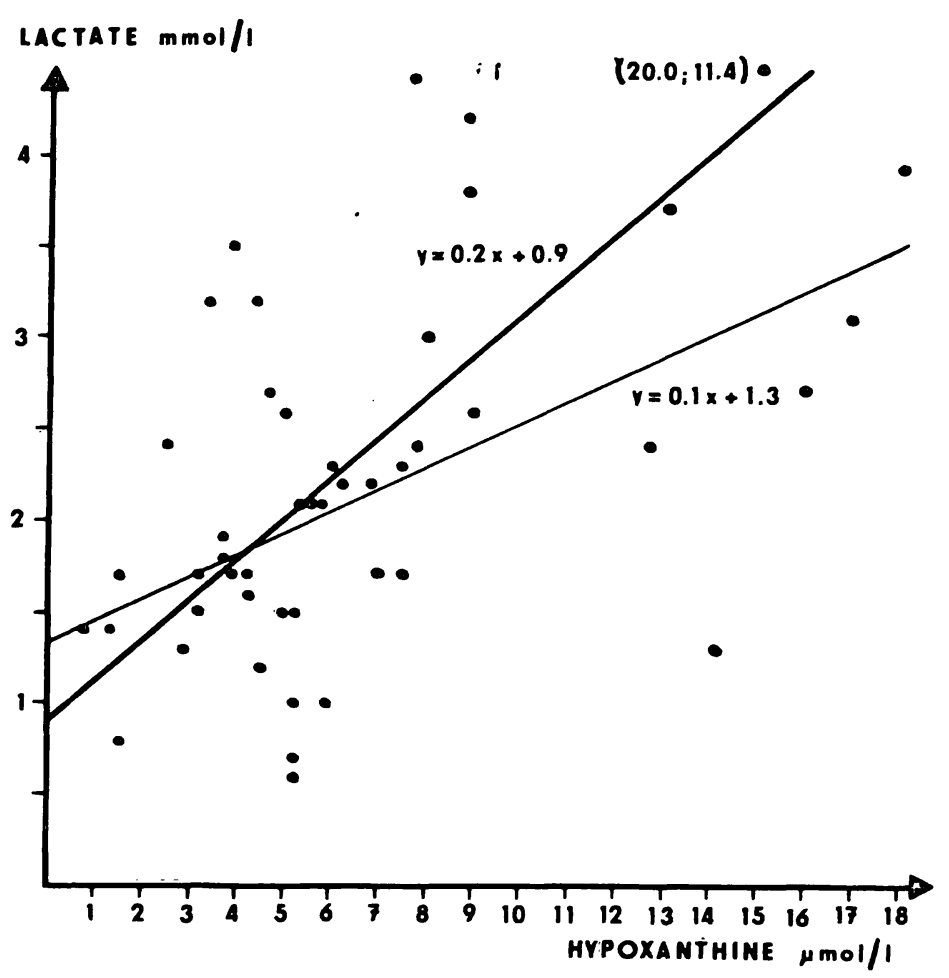

Fig. 3. Correlation between hypoxanthine and lactate concentration in the capillary blood of newborns requiring respiratory support and well prematures $(n=47, r=0.61)$ $(\longrightarrow)$. The regression curve from the reference values for hypoxanthine and lactate is indicated for comparison purposes $(\mathrm{n}=128, \mathrm{r}=0.53)(\longrightarrow)$.

\section{Discussion}

We are not aware of comparable systematic studies of norms for hypoxanthine levels in newborns. Various authors have reported a wide range of hypoxanthine levels in healthy infants and tottlers $[2,10,11,17,18,23]$. It is likely that differences are largely due to methodology $[9,13]$. It may, however, be concluded from the continual decrease of the normal values for hypoxanthine that it is elevated immediately after birth as compared to later in life. The course of lactate levels with increasing age seen by us is in agreement with observation of other authors $[1,6,28]$.

On the whole, the correlation of hypoxanthine and lactate levels in the different groups of newborns is fair at best. The results thus concur with findings of others in newborns [13] and young adults [26], whereas in animal experiments with acute hypoxemia highly significant correlations between hypoxanthine and lactate values have been observed $[19,25]$. These extreme experimen- 
tal hypoxic conditions are nowadays seen rarely, if ever, seen in neonatal intensive care.

Of 8 infants on respiratory support with signs of hypoxia only five had elevated hypoxanthine levels (Tab. V). It is to be assumed that the other three infants had sufficient physiological compensatory mechanisms as well as therapeutic measures to prevent any notable intracellular breakdown of adenine nucleotide. O'CONNOR et al. [13] found a similar low sensitivity of the hypoxanthine determination.

For the two newborns in Group C with elevated hypoxanthine levels without other indicators of hypoxia the work associated with crying or increased respiratory effort just before the sample collection might have been associated with physical stress. Physical stress may cause a brief increase of hypoxanthine levels [12]. This might also explain the two elevated hypoxanthine levels in Group B (Fig. 1).

Tab. V illustrates that of 8 newborns with signs of hypoxia elevated lactate values were found in 7 ; only in one case was the lactate level normal.

Thus, the lactate level appears to be a more sensitive parameter for hypoxia than that of hypoxanthine. This matches the theoretical assumption that during hypoxia cellular ATP concentration is initally maintained by an increased glycolysis. Only very marked $\mathrm{O}_{2}$ deficit will lead to a break down of adenine nucleotides and thus increase hypoxanthine in cells and plasma.

The 5 infants with elevated lactate concentrations without clinical hypoxia were very immature newborns from whom samples have been obtained on the first two days of life. It is conceivable that a elevation of lactate originating from the time of birth may have lasted an extended time in these infants.

\section{Summary}

This work examines the correlation between the concentration of hypoxanthine and lactate, the clinical course, and the parameters of the acid-base metabolism in newborns. In order to obtain normal values in mature, healthy newborns (Group A) 136 determinations of hypoxanthine and 126 determinations of lactate in blood were performed in the first five postnatal days. In well prematures
SAUGSTAD et al. [19, 20, 25] found in their animal experiments under specifically defined hypoxic conditions a marked correlation of hypoxanthine levels with several parameters of acid-base balance. In an other clinical study [21] the correlation between hypoxanthine on the one and $\mathrm{pH}$ or base deficit on the other side are very high. However, they are determined essentially by the extremes, fairly compatible with survival and were treated among our patients. We as well as other authors saw no correlations in newborns [13] or young adults [26].

In several studies there were correlations between the levels of lactate in the blood of asphyxiated newborns and the base deficit during and $30 \mathrm{~min}$ utes after birth $[1,8]$. The postnatal call on the buffer base content of the blood by the lactate concentration is only transient [16]. With increasing postnatal age according to our observations there does not seem to be any further correlations between lactate concentration and base deficit or between lactate and other parameters of the acidbase balance. Our patient sample was comprised of individuals with mild and moderate hypoxia. Evidently, in these infants cellular oxygen deficit was not severe enough to cause such severe disturbances of the cellular energy balance that unequivocal changes of lactate and hypoxanthine concentrations in the blood would have resulted.

For the practice of neonatology, we conclude that currently neither hypoxanthine nor lactate determinations are suitable for the recognition of hypoxia in the first week of life with sufficient sensitivity nor to characterize hypoxia as to its extent. Thus, we share the conclusion of other authors for the intranatal and immediate postnatal period $[1,13]$.

(Group B) hypoxanthine was determined 18 times and lactate 16 times. In newborns requiring oxygen therapy including ventilator support (Group $\mathrm{C}$ ) hypoxanthine and lactate were determined 36 and 31 times respectively. Hypoxanthine levels in the blood of mature healthy newborns decreased with increasing age (Tab. I). A similar course is known for lactate levels (Tab. II). In the group 
of well prematures (Group B), hypoxanthine and lactate levels have an age dependent course similar to that in group A (Tabs. III and IV).

Correlations between hypoxanthine and lactate concentrations were observed in all three groups (Fig. 3) but were not noted to be as well defined as has been seen experimentally (e.g., by SAUGSTAD) and thus confirm the clinical results of other authors.

Among the newborns requiring oxygen therapy (Group C) 7 of 36 hypoxanthine values were more than two standard deviations above those in the normal group. For lactate group $C$ infants were in 12 of 31 cases above the two standard deviation range (Fig. 1 and 2).

The hypoxanthine and lactate concentrations of group $C$ newborns were correlated with clinical and biochemical indicators of hypoxia (Tab. V). Infants with unequivocal signs of hypoxia showed elevated as well as normal hypoxanthine and lactate levels. Conversely, infants without clinical, pathological or biochemical hypoxia indicators showed in some cases elevated hypoxanthine and lactate values. On the whole, lactate levels appear to be a somewhat more sensitive indicator for hypoxia than the hypoxanthine concentration. This corresponds with the theoretical model that during hypoxia the decay of ATP may initially be inhibited by increased glycolysis.

Hypoxanthine and lactate levels in the blood of oxygen treated newborns did not correlate statistically to any of the parameters of the acid-base metabolism $\left(\mathrm{pH}, \mathrm{pO}_{2}\right.$, base deficit, $\mathrm{O}_{2}$ saturation). Our patient material included patients with predominantly mild to moderate degrees of hypoxia. Evidently, the cellular oxygen deficiency in these children was not marked enough to trigger sufficient severe disturbances in cellular energy stores to cause unequivocal changes in lactate and hypoxanthine concentrations in the blood.

For the practice of neonatology, these results allow the conclusion that neither hypoxanthine nor lactate determinations are suitable to recognize and quantify hypoxic conditions in the first week of life.

Keywords: Hypoxanthine, hypoxia, lactate, newborns, prematures.

\section{Zusammenfassung}

Hypoxanthin- und Laktatkonzentration im Blut von gesunden und von hypoxiegefährdeten Neugeborenen

In der vorliegenden Arbeit werden die Beziehungen zwischen Hypoxanthin- und Laktatkonzentration, klinischem Bild und den Parametern des Säure-Basen-Haushalts bei Neugeborenen untersucht und eingeschätzt. Zur Ermittlung von Referenzwerten wurden bei reifen, gesunden Neugeborenen (Gruppe A) in den ersten fünf postnatalen Tagen 136 Hypoxanthin- und 126 Laktatbestimmungen im Blut vorgenommen. Bei gesunden Frühgeborenen (Gruppe B) wurden Hypoxanthin 18- und Laktat 16mal und bei Neugeborenen, die einer $\mathrm{O}_{2}$-Therapie (Beatmung oder Atemunterstützung) bedurften (Gruppe C), 36- bzw. $31 \mathrm{mal}$ bestimmt.

Die Hypoxanthinkonzentration bei reifen, gesunden Neugeborenen fällt mit zunehmendem Lebensalter ab (Tab. I). Für die Laktatkonzentration ist ein ähnlicher Altersgang bekannt (Tab. II). In der Gruppe der gesunden Frühgeborenen (Gruppe B) ist für die Hypoxanthin- und die Lak tatkonzentration ein ähnlicher altersabhängiger Verlauf ersichtlich wie in Gruppe A (Tab. III und IV).

Beziehungen zwischen der Hypoxanthin- und der Laktatkonzentration konnten zwar in allen drei Neugeborenengruppen beobachtet werden (Abb. 3); sie waren jedoch nicht von der aus experimentellen Befunden (z. B. von SAUGSTAD) bekannten Eindeutigkeit und bestätigten damit die Ergebnisse klinischer Untersuchungen anderer Autoren.

Bei den $\mathrm{O}_{2}$-therapiebedürftigen Neugeborenen (Gruppe C) befanden sich 7 von 36 Hypoxanthinwerten oberhalb der $2 \mathrm{~s}$-Grenze der Referenzgruppe, beim Laktat lagen in Gruppe C 12 von 31 Werten oberhalb des 2 s-Bereichs (Abb. 1 und 2).
In der Gruppe der $\mathrm{O}_{2}$-therapiebedürftigen Neugeborenen wurden die ermittelten Hypoxanthin- bzw. Laktatkonzentrationen mit definierten klinischen oder biochemischen Hinweisen für eine Hypoxie verglichen (Tab. V). Bei Kindern mit eindeutigen Hypoxiehinweisen waren sowohl erhöhte als auch normale Hypoxanthin- und Laktatkonzentrationen nachweisbar; umgekehrt traten bei Kindern, bei denen sich klinisch oder pathobiochemisch keine Hinweise auf eine Hypoxie fanden, auch erhöhte Hypoxanthin- und Laktatwerte auf. Insgesamt scheint die Laktatkonzentration ein etwas empfindlicherer Hypoxieparameter als die Hypoxanthinkonzentration zu sein, was auch der theoretischen Vorstellung entspricht, daß bei einer Hypoxie ein ATP-Abbau zunächst durch eine gesteigerte Glykolyse verhindert werden kann.

Im Blut der $\mathrm{O}_{2}$-therapiebedürttigen Neugeborenen zeigten sowohl die Hypoxanthin- als auch die Laktatkonzentration zu keinem der Parameter des Säure-Basen-Haushalts $\left(\mathrm{pH}, \mathrm{pO}_{2}\right.$, Basendefizit, $\mathrm{O}_{2}$-Sättigung) eine statistische Beziehung.

In unsere Untersuchung wurden Patienten aufgenommen, die vorwiegend milde und mittelschwere Hypoxiezustände aufwiesen. Offensichtlich war bei diesen Kindern der zelluläre $\mathrm{O}_{2}$-Mangel noch nicht ausgeprägt genug, um zu so schwerwiegenden Störungen der zellulären Energiebereitstellung $\mathrm{zu}$ führen, daß eindeutige Veränderungen der Laktat- und Hypoxanthinkonzentration im Blut resultierten.

Für die neonatologische Praxis muß aus den vorliegenden Ergebnissen geschlußfolgert werden, daß sowohl die Hypoxanthin- als auch die Laktatbestimmung im Blut derzeit nicht geeignet sind, hypoxische Zustände in der ersten Lebenswoche hinreichend sicher zu erfassen und in ihrem Ausmaß zu charakterisieren.

Schlüsselwörter: Frühgeborene, Hypoxanthin, Hypoxie, Laktat, Neugeborene. 


\section{Résumé}

Concent ration sanguine d'hypoxanthine et do lactate choz los nouvenux-nćs en bonne santé ot hypoxiques

Ce travail examine la corrélation entre la concentration d'hypoximthine of de lactales, l'ovolution ellinlaue of les paramètres du métabolisme acido-basicgue ehez les nonveanu-nós. Pour oblonir des valeurs normales chez los nouvenux-nd́s maltures, on bonno sunté (groupe $\Lambda$ ) on a rétulisó all cours des 5 premiurs jours post-millaux 136 dosages d'hypoxmulhine of 126 dosages de lact:ates. Choz les prématurés bien portants (groupe B) on a dosó l'hypoxunthine 18 fois of les lactatus 16 lols. Chez les nouveauxnós ayant bosoin d'une oxygénolliérapie, y compris uno ventilation assisté (groupe ()) Plhypoxanthine of les lactates onl élé mesurés respectivement 36 et 31 fois.

Les Laux sanguins d'hypoxanthino des nouveaux-nés malures bion portants diminuont avec l'age (T'nb. I). On connait l'ovolution analoguo dos (aux do laclates (T'ab). II). Danıs le groupe des prómaturés bion portants (groupe B) los latux d'hypoxanthino et de lactates ont une évolution dopondant do l'ige similatire î eelle dil group) $\wedge$ ('T:ill. III ol IV).

On a obsurvé dos corrélitions entre les concuntrations ('hypoxanthino of de lactales dans les 3 groupes (ligg. 3) mais pas alussi précises que eulles obscivécs uxpórimentalument (pill exemple par SAU(iSTAD) et cola confirmo les rúsultats cliniquos d'iull ress autours.

Parmi los nouvoaux-nés ayant nécessile une oxygénotlórapie (groupe C) 7 des 36 valcurs d'hypoxanthine depassaiont de deux dévialions standards les valeurs du groupe normal. Quant aux lactates chez los onfints du groupe ${ }^{\circ}$ dans 12 cus sur 31 ils étaiont plus olevés de doux déviarons stundards (Pigs. 1 of 2 ).
Les concentrations d'hypoxanthine of de lactales choz los nouvenux-nés du groupse $C$ étaicut corrélós avoc los indiculcurs clinigues of hiocloumigues d'hypoxie (Tab. V). Lus cufants presentant des signes indubitablus d'hypoxio ont montré des taux d'hypoxanthino of do lacintos élovés aussl bion quie normalux.

Réciproquemont, les enfinnts sans indicatours cliniquos, pathologigues ou hiochimicules d'hypoxio ont presenté dans gluclyues cus dos valeurs ślovós d'hypoxanihino ot de lactates.

Cilobalement, des taux de lactates apparaissent on qualejue sorte comme un Indienteur d'liypoxio plus sensible que la concuntration d'hypoxanthino. Cola corruspond nvec le

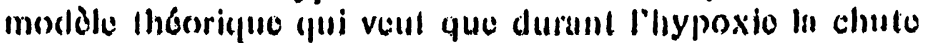
de l'A TrP peut étre lnhibéo initialemont par uno angenentalion do lin glycolyso.

l.es taux sanguins d'hypoxunthine of de linctalos clies les nouveaux-nós nyunt une oxygénolherrapic no sont pas

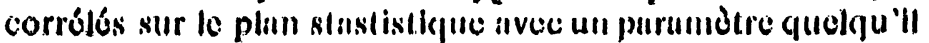

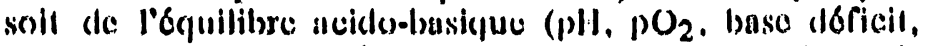
saluration en $\mathrm{O}_{2}$ ). Leseliantillon de nos pittionts inclunit de fugeon próclominanto des hypoxios d'importanco moyonno al modérós. A l'éviduncic, le déficil eellulatro on oxygène ches cos enfanls n'étult pas assez marqué pour déclencher des troubles sulfisammont sévdros des réservess ónergéticgues eellulaleses pour entrainor dess modifientions sans éfluivocfues des eonconlrallons sanguines ell lactales el sin hypoxinnthine.

Pour la conduile pratigue en nóonatolngies. cen rósultads pormottoni la conclusion que ni la dótormination de P'hypoxantlino ni cello des lactatos no sont des paramòtres adóquats pour reconnaitro et quantifier to rotentissomoni do l'hypoxio au cours de la première semaino do vio.

Mots-clés: Ilypoxanthine, hypoxic, lactalcs, nouveuux-nés, prómaturés.

\section{Bibliography}

11) BRATTIBBY, I. R., S. SWANSTROM: Arturial lacinte and pyruvate contentration in the normal and usphyxiuted nowborn intant. In: BossAR'l, H., C. PERRET: bictilte in acute conditions. Karger. Bissel 1979, p. 56

12) BRATTIBY, L. IE., S. SWANS'TROM: Hypoxanthino concentration in plasma during the lirst two hours uller birlh in normal innd asphysiated inliants. Podiuts. Rus. 16 (1982) 152

13) CARDINER. D. G.: A rapid and sensitive fluorimetric isssily for aclonosine, inosinc, und hypoxanthino. Anul. Biuchum. 95 (1979) 377

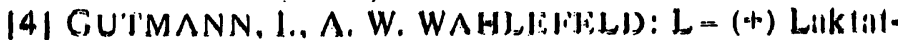
Bustimmung mil Laklat-Dehydrogenuse und NAD). In: BESRGMIIYLR, H. U.: Melloden der Baymatisclien Analyse. Bund II. Vorlag Cheinic, Weinhein 1974. p. 1510

15) HUCKABELE. W. R.: Rulutionships of pyruvile and lactalo during :macrobic motabolism. J. Clin. Invost. $37(1958) 244$

|OI LAU'TNER, II., D.'KAISIER. L. WIERNLER: DOI V(IIlaul dor Laktat- und Pyruvalkongentrationen und des Laklul-1'yruvat-Ougtionlen in den ussten 18 Le:hensstumden. Mschr. Kinderheilk. 116 (1968) 257

$17 \mid$ I,III, A., P. TUCHSCHMII), M. SII,BH:RS(CHMII)T el al.: Arteriul cord bloos hyposanthine and intrit. uterine hypoxi:. In: 5 th lisuropenn Congress of Peri. natil Medicinc. Abstracts of true enmmunications. Uppsiala 1976.11.21

|R| LOW. J. A.. S. R. PANCIIAM, D. WOR'IHINGTON of al.: The ancid-hase and biochemical chameleristles of intripartum lutal usphyxin. AmI. J. Obstel. Gyne(o). 121 (1975) 446

19 LUN, A., D). JUN(i, R. P()HLl: ol al.: HypoxunthinKonzontration in Blul von Nenguborenen. Z. Mod. 1.a1).-1)ing 24 (1983) 47

II0| LUN, A., R. POHIIL, A. IIAR'IWIGi el ul.: Verhullen dor Ilypoxanthin-Konzontrution lan Plasinn bui Nougelorenen und Kindern mit Horghishlern. D). Gissundl1.-Wesion $35(1980)$ 1006

111 MAASHE. M., D. SC'HRAMM, B. SCHIIIDT ol il.:

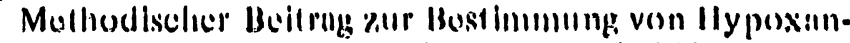
thin Im Sortum als Hypoxiepmrameler boi Neugeborenen. Kinderourz.11. Prox. $4 \%(19 \%)$ 108 
[12] MALlmanN, B., A. LUN, R. POHLE: Biochemische Parameter im Serum vor und nach körperlicher Belastung. 3. Mitteilung: Hypoxanthin-Konzentration im Blut. Medizin und Sport (submitted)

[13] O'CONNOR, M. C., R. A. HARKNESS, R. J. SIMMONDS et al.: The measurement of hypoxanthine, xanthine, inosine and uridine in umbilical cord blood and fetal scalp blood samples as a measure of fetal hypoxia. Br. J. Obstet. Gynaecol. 88 (1981) 381

[14] Pஷ̉IBYLOVÁ, H., K. ZNAMENÁĊEK: The effect of body temperature on the level of carbohydrate metabolites and oxygen consumption in the newborn. Pediatrics 37 (1966) 743

[15] SACHS, L.: Angewandte Statistik. Springer, BerlinHeidelberg-New York 1978

[16] SALING, E.: Die $\mathrm{O}_{2}$-Sparschaltung des fetalen Kreislaufes. Geburtsh. u. Frauenheilk. 26 (1966) 413

[17] SAUGSTAD, O. D.: Hypoxanthine as a measurement of hypoxia. Pediatr. Res. 9 (1975) 158

[18] SAUGSTAD, O. D.: The determination of hypoxanthine and xanthine with a $\mathrm{pO}_{2}$ electrode. Pediatr. Res. 9 (1975) 575

[19] SAugstad, O. D., A. O. AASEN, O. HeTland: Plasma hypoxanthine levels in pigs during acute hypoxemia. Eur. Surg. Res. 10 (1978) 314

[20] SAUGSTAD, O.D., G. B $\varnothing$, T. $\emptyset$ STREM et al.: Hypoxanthine levels of plasma during hypoxemia in dogs. Eur. Surg. Res. 9 (1977) 23

[21] SAUGSTAD, O. D., L. GLUCK: Plasma hypoxanthine levels in newborn infants: A specific indicator of hypoxia. J. Perinat. Med. 10 (1982) 266

[22] SAUGSTAD, O. D., T. DSTREM: Hypoxanthine and urate levels of plasma during and after hemorrhagic hypotension in dogs. Eur. Surg. Res. 9 (1977) 48
[23] SWANSTRÖM, S., L. E. BRATTEBY: Hypoxanthine as a test of perinatal hypoxia as compared to lactate, base deficit, and' $\mathrm{pH}$. Pediatr. Res. 16 (1982) 156

[24] THIRINGER, K., S. BLOMSTRAND, K. KARLSSON et al.: Cerebral arterio-venous difference for hypoxanthine (HX) during graded asphyxia in the fetal lamb. In: 7th European Congress of Perinatal Medicine, Abstracts. Barcelona 1980, p. 162

[25] THIRINGER, K., O. D. SAUGSTAD, I. KJELLMER: Plasma hypoxanthine in exteriorized, acutely asphyxiated fetal lambs. Pediatr. Res. 14 (1980) 905

[26] TUCHSCHMID, P.E., U. BOUTELliER, E. A. KOLLER et al.: Comparison of hypoxanthine, lactate, and ECG signs as indicators of hypoxia. Pediatr. Res. 15 (1981) 28

[27] WEBER, E.: Grundriß der biologischen Statistik. Fischer, Jena 1980

[28] ZNAMENÁČEK, K., H. PŘIBYLOVÁ: Some parameters of respiratory metabolism in the first 3 days after birth. Acta Paediatr. Scand. 53 (1964) 241

Received April 31, 1983. Revised February 1, 1984. Accepted February 7, 1984.

Prof. Dr. L. Grauel Abteilung Neonatologie der Kinderklinik des Bereichs Medizin (Charité) der Humboldt-Universität Schumannstraße 20/21 1040 Berlin, GDR 